\title{
Relationship of ozone and carbon monoxide over North America
}

\section{Citation}

Chin, Mian, Daniel J. Jacob, J. William Munger, David D. Parrish, and Bruce G. Doddridge. 1994. "Relationship of Ozone and Carbon Monoxide over North America." Journal of Geophysical Research 99 (D7): 14565. doi:10.1029/94jd00907.

\section{Published Version}

doi:10.1029/94JD00907

\section{Permanent link}

http://nrs.harvard.edu/urn-3:HUL.InstRepos:14121778

\section{Terms of Use}

This article was downloaded from Harvard University's DASH repository, and is made available under the terms and conditions applicable to Other Posted Material, as set forth at http:// nrs.harvard.edu/urn-3:HUL.InstRepos:dash.current.terms-of-use\#LAA

\section{Share Your Story}

The Harvard community has made this article openly available.

Please share how this access benefits you. Submit a story.

\section{Accessibility}




\title{
Relationship of ozone and carbon monoxide over North America
}

\author{
Mian Chin, Daniel J. Jacob, and J. William Munger \\ Division of Applied Sciences and Department of Earth and Planetary Sciences, Harvard University, \\ Cambridge, Massachusetts
}

David D. Parrish

NOAA Aeronomy Laboratory, Boulder, Colorado

\author{
Bruce G. Doddridge \\ Department of Meteorology, University of Maryland, College Park
}

\begin{abstract}
Observations at sites in eastern North America show a strong correlation between $\mathrm{O}_{3}$ and $\mathrm{CO}$ concentrations in summer, with a consistent slope $\Delta \mathrm{O}_{3} / \Delta \mathrm{CO} \approx$ 0.3. Observations in the aged Denver plume at Niwot Ridge, Colorado, also show a strong correlation but with $\Delta \mathrm{O}_{3} / \Delta \mathrm{CO}=0.15$. These data offer a sensitive test for evaluating the ability of photochemical models to simulate production of $\mathrm{O}_{3}$ over North America and its export to the global atmosphere. Application to the Harvard/Goddard Institute for Space Studies three-dimensional, continental-scale model shows that the model gives a good simulation of the observed $\mathrm{O}_{3}-\mathrm{CO}$ correlations and of the associated $\Delta \mathrm{O}_{3} / \Delta \mathrm{CO}$. This successful simulation lends support to model estimates of 6 Gmol d $\mathrm{d}^{-1}$ for the net $\mathrm{O}_{3}$ production in the U.S. boundary layer in summer (corresponding to a net $\mathrm{O}_{3}$ production efficiency of 5.5, which is the number of $\mathrm{O}_{3}$ molecules produced per molecule of $\mathrm{NO}_{x}$ consumed) and $70 \%$ for the fraction of the net production that is exported to the global atmosphere. Export of U.S. pollution appears to make a significant contribution to total tropospheric $\mathrm{O}_{3}$ over the northern hemisphere in summer. Simple interpretation of observed $\Delta \mathrm{O}_{3} / \Delta \mathrm{CO}$ as an $\mathrm{O}_{3} / \mathrm{CO}$ anthropogenic enhancement ratio is shown to underestimate substantially anthropogenic $\mathrm{O}_{3}$ production, because $\mathrm{O}_{3}$ and $\mathrm{CO}$ concentrations are negatively correlated in the absence of photochemistry. It is also shown that concurrent observations of $\Delta \mathrm{O}_{3} / \Delta \mathrm{CO}$ and $\Delta \mathrm{O}_{3} / \Delta\left(\mathrm{NO}_{y}-\mathrm{NO}_{x}\right)$ ratios can be used to impose lower and upper limits on the net $\mathrm{O}_{3}$ production efficiency.
\end{abstract}

\section{Introduction}

Tropospheric $\mathrm{O}_{3}$ is a key precursor of the hydroxyl radical which controls the oxidizing power of the atmosphere [Logan et al., 1981; Thompson, 1992]. Ozone is also one of the major pollutants which, in high concentration, can be harmful to human health and to plants. Large amounts of anthropogenic $\mathrm{O}_{3}$ are produced over the United States in summer by photochemical oxidation of nonmethane hydrocarbons (NMHCs) in the presence of nitrogen oxides $\left(\mathrm{NO}_{x}=\mathrm{NO}+\mathrm{NO}_{2}\right)$. Quantifying this anthropogenic source of $\mathrm{O}_{3}$ and assessing its global influence is presently a major research issue in tropospheric chemistry [Liu et al., 1987; International Global Atmospheric Chemistry (IGAC), 1992; Parrish et al., 1993].

The covariance of $\mathrm{O}_{3}$ and $\mathrm{CO}$ concentrations offers a valuable constraint for quantifying the anthropogenic source of $\mathrm{O}_{3}$. Carbon monoxide is a long-lived tracer of human activity with relatively well known sources from combustion, industry, and oxidation of hydrocarbons [Logan et al., 1981]. Several authors have used the $\mathrm{O}_{3}-\mathrm{CO}$ correlation measured from aircraft downwind of the United States to

Copyright 1994 by the American Geophysical Union.

Paper number 94JD00907.

0148-0227/94/94JD-00907\$05.00 diagnose pollution influence on $\mathrm{O}_{3}$ [Fishman and Seiler, 1983; Fishman et al., 1987; Chameides et al., 1987, 1989; Marenco and Said, 1989]. Recently, Parrish et al. [1993] made a first estimate of the export of anthropogenic $\mathrm{O}_{3}$ from North America to the North Atlantic by using the slope $\Delta \mathrm{O}_{3} / \Delta \mathrm{CO} \approx 0.3$ measured at three Canadian marine sites downwind of the United States and scaling to a CO emission inventory for the eastern United States. They concluded that export of pollution from the United States dominates over transport from the stratosphere as a source of $\mathrm{O}_{3}$ to the lower troposphere over the North Atlantic in summer.

A more detailed interpretation of $\Delta \mathrm{O}_{3} / \Delta \mathrm{CO}$ in terms of $\mathrm{O}_{3}$ production requires a three-dimensional model that can resolve complicating factors such as the effect of $\mathrm{O}_{3}$ deposition, the presence of chemical sources and sinks for $\mathrm{CO}$, and spatial variability. We present here such an analysis using a continental-scale model for $\mathrm{O}_{3}$ and its precursors over North America [Jacob et al., 1993a]. Our principal objective is to use the $\mathrm{O}_{3}-\mathrm{CO}$ correlation as a test of the ability of the model to compute production of $\mathrm{O}_{3}$ over the continent. The particular value of this test is that it normalizes $\mathrm{O}_{3}$ photochemical enhancements to a long-lived tracer of human activity. Ozone concentrations alone do not offer as sensitive a test because they include a substantial and variable background advected from the model boundaries (e.g., from the oceans or from high altitude). In rural surface 

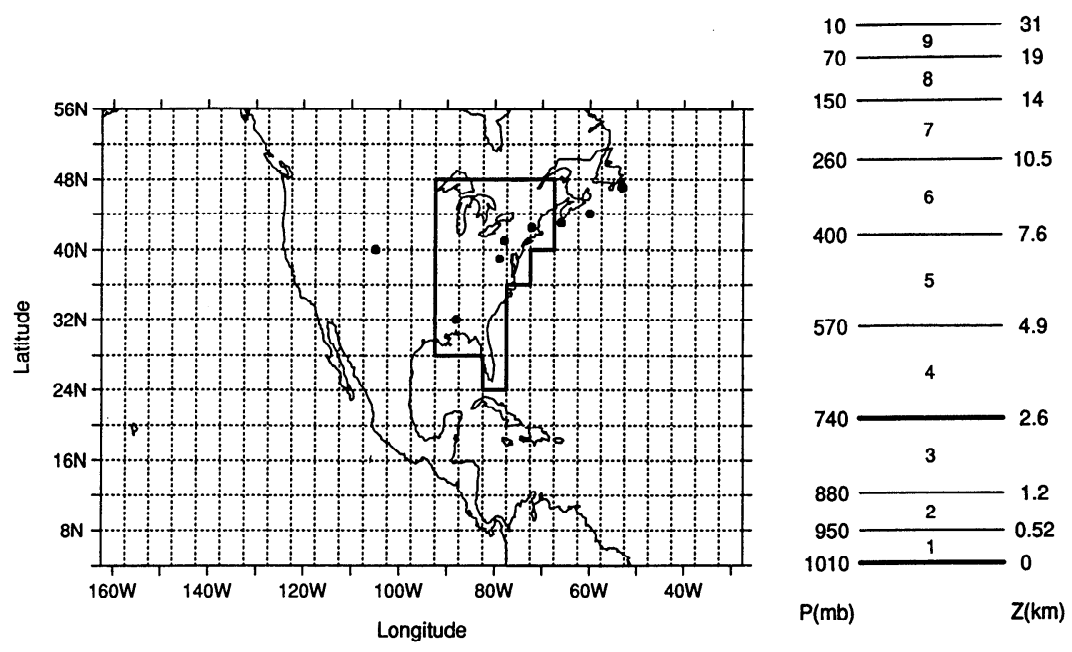

Figure 1. Model domain and grid. The vertical grid (nine layers) is defined by a sigma coordinate; pressures and altitudes at layer boundaries are shown for an atmospheric column based at sea level. Locations of the measurement sites are indicated by solid circles (see Table 1). The domain enclosed by thick lines and extending from the surface to $2.6 \mathrm{~km}$ altitude is the eastern U.S. boundary layer used in the text for budget calculations.

air over the eastern United States, about half of the mean summertime $\mathrm{O}_{3}$ concentration appears to be contributed by advection from outside North America [Jacob et al., 1993a]. The $\mathrm{O}_{3}-\mathrm{CO}$ correlation removes to a large degree the sensitivity to background. As such, it diagnoses whether the model is giving a successful simulation of $\mathrm{O}_{3}$ for the right reasons.

Section 2 gives a brief description of the model and summarizes important previous results. Section 3 presents observed $\mathrm{O}_{3}-\mathrm{CO}$ correlations at sites in North America and compares model to observations. Section 4 assesses the possibility for direct interpretation of observed $\Delta \mathrm{O}_{3} / \Delta \mathrm{CO}$ as an anthropogenic enhancement ratio. Conclusions are in section 5 .

\section{The Model}

The three-dimensional photochemical model of Jacob et al. [1993a] covers a domain including North and Central America and large portions of surrounding oceans with $4^{\circ}$ latitude $\times 5^{\circ}$ longitude grid resolution and nine vertical layers (Figure 1). Six tracers are transported, including odd oxygen (which is mainly $\mathrm{O}_{3}$ ), $\mathrm{CO}, \mathrm{NO}_{x}$, peroxyacetylnitrates (PANs), and two lumped NMHCs. Anthropogenic emissions of $\mathrm{NO}_{x}, \mathrm{CO}$, and NMHCs in North America are taken from a summer 1985 inventory compiled by the National Acid Precipitation Assessment Program (NAPAP) [Environmental Protection Agency (EPA), 1989]. Biogenic emission of isoprene and dry depositions of $\mathrm{O}_{3}, \mathrm{NO}_{x}$, and PANs, are computed using process models dependent on surface-type and meteorological variables. Chemical reaction rates are computed using the photochemical mechanism of Lurmann et al. [1986] with minor modifications [Jacob et al., 1989]. Nonlinear chemistry in urban and industrial plumes is represented with a sub-grid-nested scheme in which concentrated pollution sources are forced to age in isolation for at least 8 hours before being mixed on the grid scale [Sillman et al., 1990a].

The simulation is conducted for 3 summer months (June to
August) with 2 weeks of initialization in May. Meteorological input is provided by one summer of data from a general circulation model (GCM) developed at the Goddard Institute of Space Studies (GISS) [Hansen et al., 1983]. Meteorological variables are updated every 4 hours, and model output is also sampled every 4 hours. Boundary concentrations at the edges of Figure 1 are specified as a function of latitude, altitude, and month using observations.

The GCM is intended to simulate a typical year rather than any particular year; evaluation of model results with observations must therefore focus on seasonal statistics rather than on values for any particular day. Jacob et al. [1993a] previously evaluated the model with observed statistics for the concentrations of $\mathrm{O}_{3}$ and precursors at rural sites in the United States. The model reproduces the observed summer median $\mathrm{O}_{3}$ concentrations to within 5 ppb in most cases, except in the south central United States where concentrations are overpredicted by $15-20$ ppb due in part to insufficient ventilation. Median summertime concentrations of $\mathrm{CO}$ are simulated to within $30 \mathrm{ppb}$ at all sites, and the spatial variance of rural $\mathrm{CO}$ across the United States is well captured.

A detailed discussion of the $\mathrm{O}_{3}$ budget in the threedimensional model is given by Jacob et al. [1993b]. The net production rate of $\mathrm{O}_{3}$ in the U.S. boundary layer $(0-2.6 \mathrm{~km}$ altitude) averages $6.1 \mathrm{Gmol} \mathrm{d}^{-1}$ for the 3-month period June to August. The net $\mathrm{O}_{3}$ production efficiency $\varepsilon_{\mathrm{N}}$ (net number of $\mathrm{O}_{3}$ molecules produced per molecule of $\mathrm{NO}_{x}$ consumed, as defined by Lin et al. [1988]) has a mean value of 5.5 in the U.S. boundary layer and is more than 2 times higher in the western United States (9.1) than in the east (4.2) because of lower $\mathrm{NO}_{x}$ concentrations in the west. (Notice the slight changes of the values of $\mathrm{O}_{3}$ production rate and net $\mathrm{O}_{3}$ production efficiency from .Jacoh et al. [1993b], after correcting an error in saving those values.) Only $30 \%$ of the net $\mathrm{O}_{3}$ production in the U.S. boundary layer in the model is deposited to the region; the remaining $70 \%$ is exported to the global atmosphere. This export amounts to about one fifth of 
Table 1. $\mathrm{O}_{3}$-CO Correlations at North American Sites in Summer

\begin{tabular}{|c|c|c|c|c|c|c|c|c|}
\hline \multirow[b]{3}{*}{ Site } & \multirow[b]{3}{*}{ Location } & \multirow[b]{3}{*}{ Period } & & \multicolumn{4}{|c|}{ Observation, Model } & \multirow[b]{3}{*}{ Reference } \\
\hline & & & & \multicolumn{2}{|c|}{ Median } & \multirow[b]{2}{*}{$\underset{\mathrm{v} / \mathrm{v}}{\Delta \mathrm{O}_{3} / \Delta \mathrm{CO}}$} & \multirow[b]{2}{*}{$r^{2}$} & \\
\hline & & & $n$ & $\begin{array}{l}\mathrm{O}_{3} \\
\mathrm{ppb}\end{array}$ & $\begin{array}{l}\mathrm{CO}, \\
\mathrm{ppb}\end{array}$ & & & \\
\hline \multirow{2}{*}{ Harvard Forest, Massachusetts } & $42^{\circ} \mathrm{N}, 72^{\circ} \mathrm{W}$ & $\begin{array}{c}\text { Flatland } \\
\text { Tune to Aug }\end{array}$ & 100 & 53 & 151 & $028+002$ & 078 & \multirow{2}{*}{$\begin{array}{l}\text { J. Munger (unpublishec } \\
\text { data, 1993) }\end{array}$} \\
\hline & & & 100 & 51 & 149 & $0.29 \pm 0.02$ & 0.81 & \\
\hline \multirow[t]{2}{*}{ Scotia, Pennsylvania } & $41^{\circ} \mathrm{N}, 78^{\circ} \mathrm{W}$ & July to Aug. 1988 & 96 & 73 & 212 & $0.28 \pm 0.03$ & 0.43 & \multirow{2}{*}{$\begin{array}{l}\text { D. Parrish et al. } \\
\text { (unpublished data, } \\
\text { 1989) }\end{array}$} \\
\hline & & & & 67 & 197 & $0.32 \pm 0.02$ & 0.84 & \\
\hline \multirow[t]{2}{*}{ Kinterbish, Alabama } & $32^{\circ} \mathrm{N}, 88^{\circ} \mathrm{W}$ & June to July 1990 & 28 & 60 & 172 & $0.32 \pm 0.05$ & 0.57 & D. Parrish et al. \\
\hline & & & & 64 & 159 & $0.41 \pm 0.06$ & 0.32 & $\begin{array}{l}\text { (unpublished data, } \\
\text { 1991) }\end{array}$ \\
\hline \multicolumn{9}{|c|}{ Mountaintop } \\
\hline \multirow{4}{*}{$\begin{array}{l}\text { Shenandoah National Park, } \\
\text { Virginia } \\
\text { Niwot Ridge, Colorado }\end{array}$} & \multirow{4}{*}{$\begin{array}{c}39 \mathrm{~N}, 79 \mathrm{~W}, \\
1100 \mathrm{~m} \\
40 \mathrm{~N}, 105 \mathrm{~W}, \\
3100 \mathrm{~m}\end{array}$} & \multirow[t]{2}{*}{ June to Aug. 1989} & \multirow[t]{2}{*}{155} & 41 & 206 & \multirow{4}{*}{$\begin{array}{c}a \\
0.31 \pm 0.03 \\
0.15 \pm 0.02 \\
0.18 \pm 0.01\end{array}$} & \multirow{4}{*}{$\begin{array}{l}0.09 \\
0.56 \\
0.50 \\
0.77\end{array}$} & \multirow[t]{2}{*}{ Poulida et al. [1991] } \\
\hline & & & & 63 & 176 & & & \\
\hline & & July to Aug. 1989 & 40 & 51 & 121 & & & \multirow{2}{*}{$\begin{array}{l}\text { D. Parrish et al. } \\
\text { (unpublished data, } \\
\text { 1990) }\end{array}$} \\
\hline & & & & 65 & 131 & & & \\
\hline \multirow{3}{*}{ Seal Island, Canada } & \multirow{3}{*}{$43 \mathrm{~N}, 66 \mathrm{~W}$} & \multirow{3}{*}{ July to Aug. $1991^{M a}$} & & & & & & \multirow{3}{*}{ Parrish et al. $[1993]^{c}$} \\
\hline & & & 527 & 36 & 118 & $0.25 \pm 0.01$ & 0.77 & \\
\hline & & & & 40 & 130 & $0.30 \pm 0.01^{b}$ & 0.63 & \\
\hline \multirow[t]{2}{*}{ Sable Island, Canada } & $44 \mathrm{~N}, 60 \mathrm{~W}$ & July to Aug. 1991 & 1098 & 36 & 107 & $0.30 \pm 0.01$ & 0.73 & \multirow[t]{2}{*}{ Parrish et al. $[1993]^{c}$} \\
\hline & & & & 38 & 123 & $0.31 \pm 0.02^{b}$ & 0.59 & \\
\hline \multirow[t]{2}{*}{ Cape Race, Canada } & $47 \mathrm{~N}, 53 \mathrm{~W}$ & July to Aug. 1991 & 1035 & 29 & 116 & $0.21 \pm 0.01$ & 0.47 & \multirow[t]{2}{*}{ Parrish et al. $[1993]^{c}$} \\
\hline & & & & 35 & 125 & $0.26 \pm 0.02^{b}$ & 0.53 & \\
\hline
\end{tabular}

Observation statistics are computed from hourly average data; for flatland and mountaintop sites, only data in the time window of 1300-1700 LT and with $\mathrm{NO}_{x} / \mathrm{NO}_{y}<0.3$ are used (see text). Model statistics are computed from output sampled every 4 hours (model time step), in the 1300-1700 LT window for continental sites, and at all times of day at marine sites.

${ }^{a}$ Observed $\mathrm{O}_{3}$ and $\mathrm{CO}$ concentrations are not correlated.

${ }^{b}$ Model correlations are computed for marine sites after removing points with $\mathrm{O}_{3}$ less than $35 \mathrm{ppb}$ and $\mathrm{CO}$ less than $120 \mathrm{ppb}$ (background conditions), to focus on the pollution signal.

${ }^{c}$ September data reported by Parrish et al. are not included in the statistics.

the cross-tropopause transport of $\mathrm{O}_{3}$ over the entire northern hemisphere in summer, implying that $\mathrm{O}_{3}$ produced in the United States makes a significant contribution to tropospheric $\mathrm{O}_{3}$ on the hemispheric scale.

\section{3. $\mathrm{O}_{3}$-CO Correlations}

Table 1 summarizes observed and simulated $\mathrm{O}_{3}-\mathrm{CO}$ correlation statistics for eight nonurban sites in North America where at least 1 month of observations are available in summer (June to August). Site locations are shown in Figure 1. For continental sites we restrict our attention to the 1300-1700 LT window, when surface air is most likely representative of the boundary layer. Such a restriction is not needed at marine sites where we use data for all times of day. The model gives one value per day in the 1300-1700 LT window at any site, the exact hour depending on longitude (1300 LT in Colorado, 1500 LT on the East Coast of the United States); we use that value for constructing model statistics. All statistics in the model are constructed for June to August ( $n=92$ points at continental sites; $n=552$ points at marine sites), even when the observations cover only a fraction of that period.

Figure 2 plots observed $\mathrm{O}_{3}$ versus $\mathrm{CO}$ concentrations at Harvard Forest in central Massachusetts. There is no significant correlation because of a number of points with elevated $\mathrm{CO}$ but low $\mathrm{O}_{3}$, representing fresh pollution plumes that have not yet realized their $\mathrm{O}_{3}$ production potential. Produc- tion of $\mathrm{O}_{3}$ over the United States in summer is mostly $\mathrm{NO}_{x}$ limited [Trainer et al., 1987; Sillman et al., 1990b; McKeen et al., 1991; Chameides et al., 1992]; therefore realization of the $\mathrm{O}_{3}$ production potential can be diagnosed by the $\mathrm{NO}_{x}$ / $\mathrm{NO}_{y}$ concentration ratio where $\mathrm{NO}_{y}$ represents the sum of $\mathrm{NO}_{x}$ and its oxidation products [Trainer et al., 1993]. Figure 3 plots the $\mathrm{NO}_{x} / \mathrm{NO}_{y}$ concentration ratio at Harvard Forest against the standard normal distribution. Two distinctly different populations are found: $\mathrm{NO}_{x} / \mathrm{NO}_{y}<0.3$ (photochemically aged rural air) and $\mathrm{NO}_{x} / \mathrm{NO}_{y}>0.3$ (fresh pollution). The rural air data (solid circles in Figure 2) show a strong correlation between $\mathrm{O}_{3}$ and $\mathrm{CO}$ concentrations $\left(r^{2}=0.78\right)$. This correlation is insensitive to small changes in the $\mathrm{NO}_{x} / \mathrm{NO}_{y}$ criterion (using $\mathrm{NO}_{x} / \mathrm{NO}_{y}<0.2$ as the criterion does not alter the correlation or the slope).

Figure 4 compares model results with rural observations (diagnosed by $\mathrm{NO}_{x} / \mathrm{NO}_{y}<0.3$ ) at the five flatland and mountaintop sites listed in Table 1. The sites were chosen for the availability of concurrent observations for $\mathrm{O}_{3}, \mathrm{CO}, \mathrm{NO}_{x}$, and $\mathrm{NO}_{y}$. The measurements at Shenandoah include NO and $\mathrm{NO}_{y}$ concentrations but not $\mathrm{NO}_{2}$ [Doddridge et al., 1992]; we estimate the $\mathrm{NO}_{2}$ concentrations at that site from $\mathrm{NO} / \mathrm{NO}_{2} / \mathrm{O}_{3}$ photostationary steady state [Leighton, 1961], using local UV flux measurements to estimate the $\mathrm{NO}_{2}$ photolysis rate constant [Madronich, 1987]. Selection of data with $\mathrm{NO}_{x} / \mathrm{NO}_{y}<0.3$ is not possible in the model because $\mathrm{NO}_{y}$ is not a tracer; however, it is not necessary 


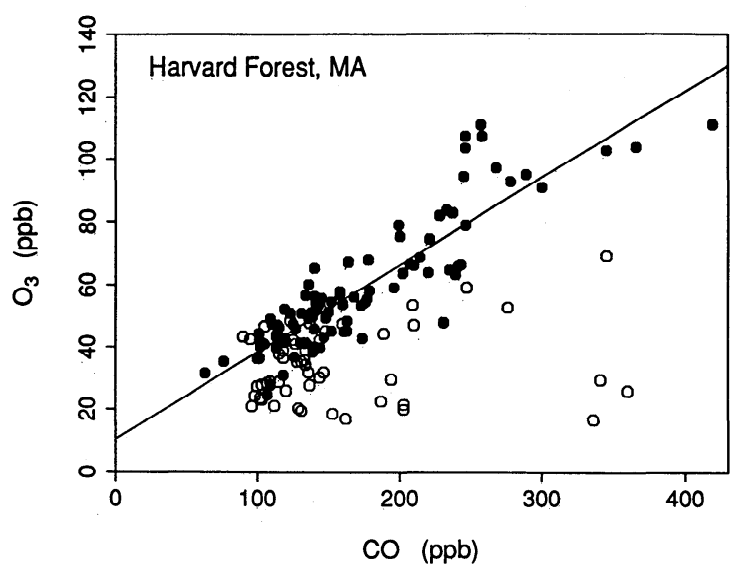

Figure 2. Hourly averaged $\mathrm{O}_{3}$ and $\mathrm{CO}$ concentrations measured at Harvard Forest, Massachusetts, in June to August, 1300-1700 ESI, 1990-1992. Solid and open circles represent hourly periods with a $\mathrm{NO}_{x} / \mathrm{NO}_{y}$ concentration ratio less or greater than 0.3 , respectively.

since urban and industrial pollution plumes are isolated in the model with the subgrid scheme.

The observations at Harvard Forest, Scotia (Pennsylvania), and Kinterbish (Alabama) show significant correlation between $\mathrm{O}_{3}$ and $\mathrm{CO}$ concentrations, with $\Delta \mathrm{O}_{3} / \Delta \mathrm{CO} \approx 0.3$ at all three sites (Table 1). We find excellent agreement between model and observations at Harvard Forest for $\mathrm{O}_{3}$ and $\mathrm{CO}$ concentrations and for the associated $\Delta \mathrm{O}_{3} / \Delta \mathrm{CO}$ (Figure $4 a)$. The observations at Scotia are also well reproduced by the model, although the model has less scatter (Figure 4b). The model also reasonably agrees with the observations at Kinterbish; although the slope in the model is somewhat higher than in the observations (Figure 4c), they overlap within the standard error. The model does not, in general, capture the extremes in the observed concentrations, in part because of spatial averaging on the $4^{\circ} \times 5^{\circ}$ grid scale.

Results for Shenandoah National Park, Virginia (mountaintop site, $1100 \mathrm{~m}$ altitude) are shown in Figure 4d. The observations show no significant $\mathrm{O}_{3}$ - $\mathrm{CO}$ correlation, while the model shows a strong correlation with slope $\Delta \mathrm{O}_{3} / \Delta \mathrm{CO} \approx$ 0.3 . The median concentration of $\mathrm{O}_{3}$ in the model is $22 \mathrm{ppb}$ higher than observed, while the median concentration of $\mathrm{CO}$ is $30 \mathrm{ppb}$ lower. Model statistics are for the lowest layer (0-500 m altitude) to account for the upslope circulation in the daytime [Poulida et al., 1991]; however, model results in layer 2 (corresponding to the actual altitude of the site) are not significantly different. The observations are from the summer of 1989, which was unusually cold, cloudy, and rainy; mean $\mathrm{O}_{3}$ concentrations at the site that summer were $10 \mathrm{ppb}$ lower than the average for the past six summers [Poulida et al., 1991].

Results for Niwot Ridge, Colorado (3100 m) are shown in Figure 4e. The observations at Niwot Ridge sample, in general, either relatively clean air advected from the west or boundary layer air transported upslope from the east and contaminated by the Denver metropolitan area [Parrish et al., 1990]. The $\mathrm{O}_{3}-\mathrm{CO}$ correlation in the observations is driven by the Denver plume. We show in Figure 4e model results for air at the altitude of Niwot Ridge (open squares) and for the 4- to 8-hour-old Denver plume resolved with the subgrid scheme (open triangles). Model results seem consis- tent with observations. We find that $\Delta \mathrm{O}_{3} / \Delta \mathrm{CO}$ at Niwot Ridge is markedly lower than at rural eastern U.S. sites, both in the observations and in the model (Table 1). This result can be explained by the low $\mathrm{NO}_{x} / \mathrm{CO}$ emission ratio in the Denver metropolitan area (0.14) as compared to the average for the eastern United States (0.23) [EPA, 1989]. The low $\mathrm{NO}_{x} / \mathrm{CO}$ emission ratio in Denver reflects the dominance of mobile sources and fuel-rich combustion in automobiles not tuned to the local altitude of $1600 \mathrm{~m}$ [Parrish et al., 1991].

Figure 5 compares model and observations at three Canadian marine sites [Parrish et al., 1993]. These sites are downwind of the northeastern United States in the prevailing summertime circulation [Wendland and Bryson, 1981]. The observations indicate $\Delta \mathrm{O}_{3} / \Delta C \mathrm{C}$ in the range of 0.21 to 0.30 , similar to values at eastern U.S. sites (Table 1). Model results are in good agreement. The variance in the model is far less than observed, certainly in part because aged pollution plumes are forced to dilute on the $4^{\circ} \times 5^{\circ}$ grid scale (no cross-gridbox advection is allowed for subgrid plumes in the model).

Our analysis indicates that $\Delta \mathrm{O}_{3} / \Delta \mathrm{CO} \approx 0.3$ is a uniform characteristic of boundary layer air over eastern North America in summer. Data for the free troposphere from the Arctic Boundary Layer Expeditions (ABLE) 3A and 3B [Harriss et al., 1992, 1994] are generally consistent with this result. Wofsy et al. [1992] measured $\Delta \mathrm{O}_{3} / \Delta \mathrm{CO}$ in the range 0.17-0.62 at 3-6 km altitude during an ABLE 3A flight along the eastern seaboard from Maine to Virginia. They measured a negative $\Delta \mathrm{O}_{3} / \Delta C O$ below $1.5 \mathrm{~km}$ on the same flight, evidently due to $\mathrm{O}_{3}$ deposition. Data from ABLE 3B show $\Delta \mathrm{O}_{3} / \Delta \mathrm{CO}$ in the range $0.20-0.69$ for anthropogenic pollution plumes sampled in the free troposphere over eastern Canada [Mauzerall et al., 1993].

\section{Interpretation}

We have shown that the three-dimensional model of Jacob et al. [1993a] reproduces closely the $\mathrm{O}_{3}-\mathrm{CO}$ correlation and slope $\Delta \mathrm{O}_{3} / \Delta \mathrm{CO}$ for all available sites in North America except Shenandoah National Park. This finding, combined with the generally good simulation of $\mathrm{O}_{3}$ and $\mathrm{CO}$ concentra-

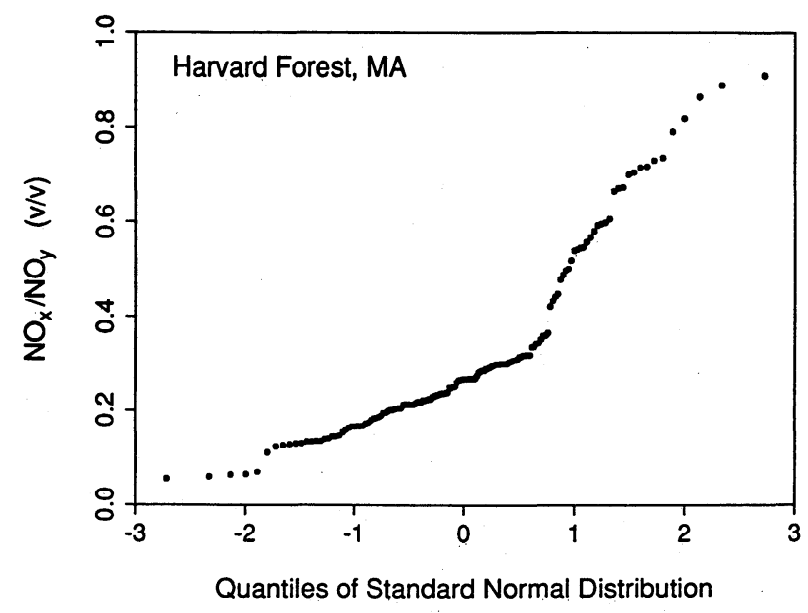

Figure 3. The $\mathrm{NO}_{x} / \mathrm{NO}_{y}$ concentration ratio measured at Harvard Forest (for the same time period as in Figure 2) plotted against the standard normal distribution. 
tions, lends confidence in the ability of the model to compute anthropogenic production of $\mathrm{O}_{3}$ over the United States and the export of $\mathrm{O}_{3}$ to the global atmosphere. Detailed discussion of model results, including $\mathrm{O}_{3}$ budgets, is given by Jacob et al. [1993b].

We evaluate here the potential for a more direct interpretation of $\Delta \mathrm{O}_{3} / \Delta \mathrm{CO}$ as an $\mathrm{O}_{3} / \mathrm{CO}$ anthropogenic enhancement
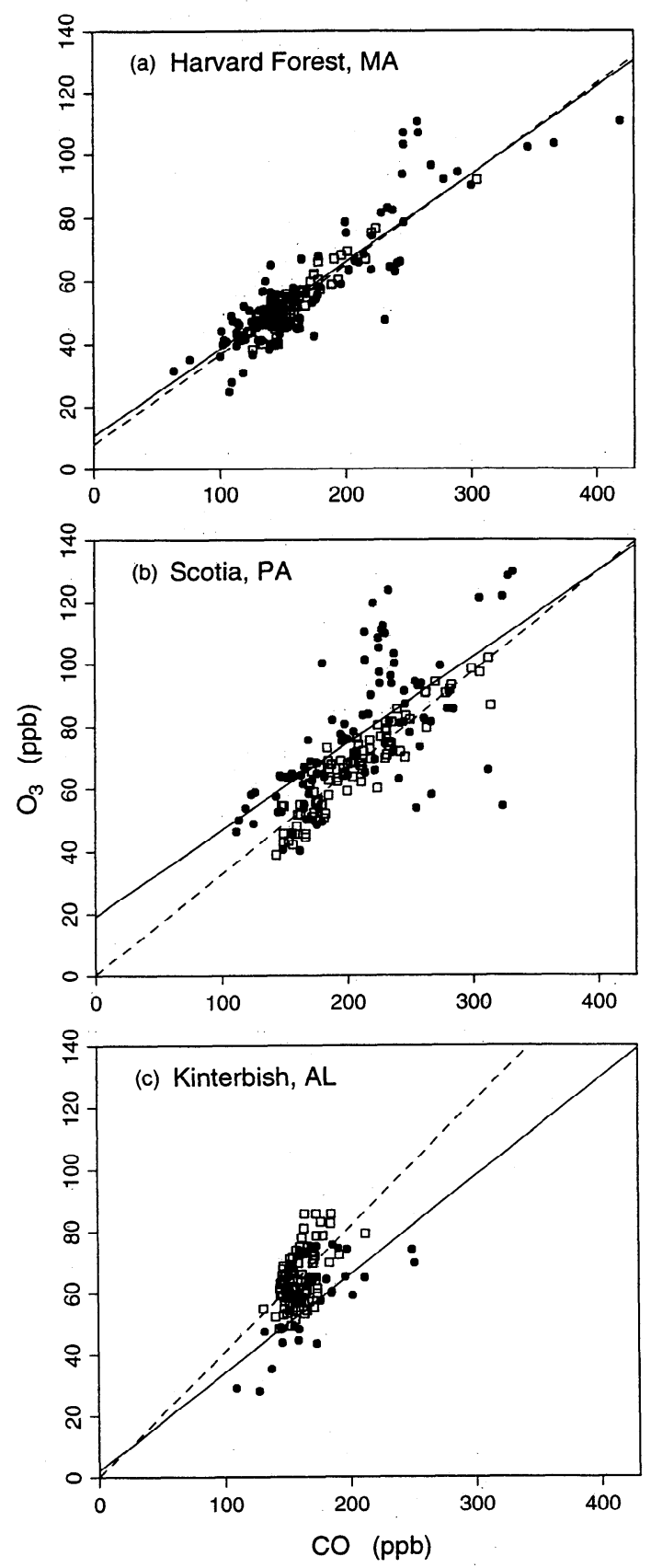

Figure 4. Observed and simulated $\mathrm{O}_{3}$ and $\mathrm{CO}$ concentrations at five U.S. sites: (a) Harvard Forest, Massachusetts; (b) Scotia, Pennsylvania; (c) Kinterbish, Alabama; (d) Shenandoah National Park, Virginia; and (e) Niwot Ridge, Colorado. Details of the data are given in Table 1. Solid circles are observations and open squares are model values. In Figure $4 \mathrm{e}$, model results are shown also for the aged Denver plume sampled with the sub-grid-nested scheme (open triangles). Lines are linear regressions to the observations (solid) and to the model results (dashed).
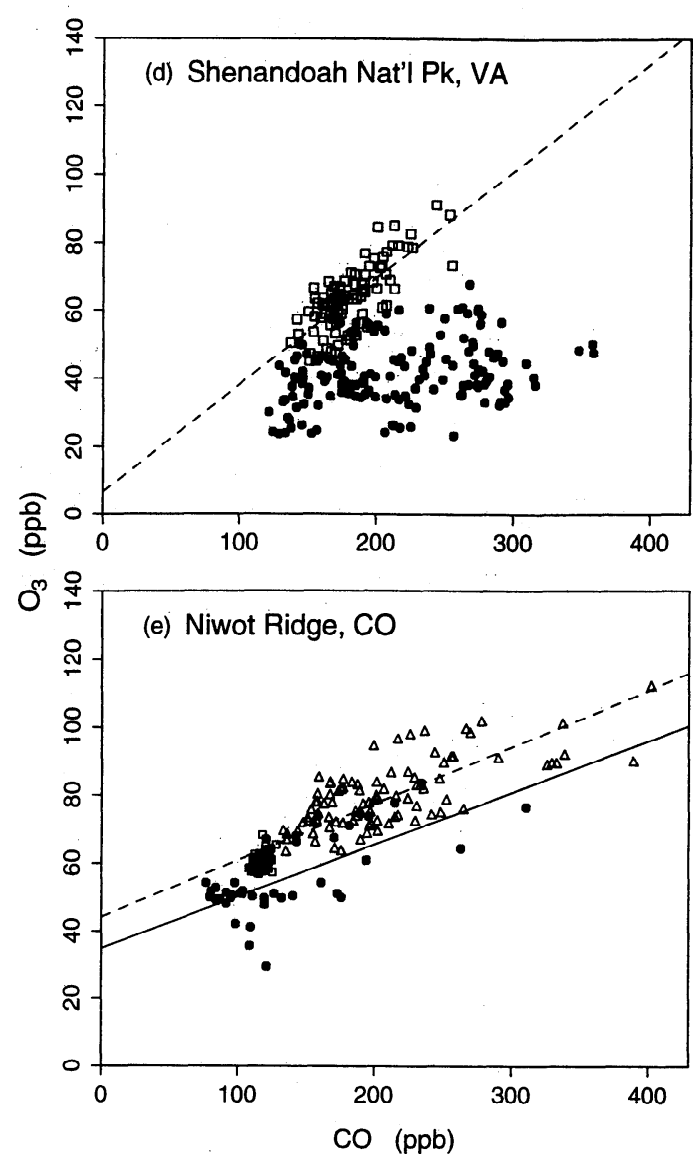

Figure 4. (continued)

ratio. Parrish et al. [1993] previously used this interpretation to estimate the export of $\mathrm{O}_{3}$ from the United States to the North Atlantic. They multiplied the observed $\Delta \mathrm{O}_{3} / \Delta C O \approx$ 0.3 at the Canadian marine sites of Table 1 by a $\mathrm{CO}$ emission inventory for the United States east of Mississippi River (approximately east of $92^{\circ} \mathrm{W}$ ) and inferred an export flux of $1.1 \mathrm{Gmol} \mathrm{d}^{-1}$ for anthropogenic $\mathrm{O}_{3}$ out of the eastern United States (mostly, they assumed, to the North Atlantic). We find however in the model an export flux of $1.6 \mathrm{Gmol} \mathrm{d}^{-1}$ for anthropogenic $\mathrm{O}_{3}$ out of the same region; this flux is $45 \%$ higher than estimated by Parrish et al. [1993], even though $\Delta \mathrm{O}_{3} / \Delta \mathrm{CO}$ in the model is indistinguishable from the observations. There are two principal reasons for the difference, as discussed below.

First, the scaling of $\Delta \mathrm{O}_{3} / \Delta \mathrm{CO}$ as done by Parrish et al. [1993] could be improved by accounting for chemical sources and sinks of $\mathrm{CO}$ in addition to direct emission. Table 2 gives an inventory of $\mathrm{CO}$ sources and sinks for the continental boundary layer of the eastern United States in the three-dimensional model. Direct emission represents only $60 \%$ of the total $\mathrm{CO}$ source; the balance is contributed by atmospheric oxidation of hydrocarbons, in particular isoprene $(20 \%)$. This chemical source is compensated by a strong chemical loss, reflecting the high concentrations of both $\mathrm{CO}$ and $\mathrm{OH}$ over the eastern United States. Overall, the net source of $\mathrm{CO}$ in the boundary layer of the eastern United States is $18 \%$ higher than the emission flux.

A more fundamental difficulty in interpreting observed $\Delta \mathrm{O}_{3} / \Delta \mathrm{CO}$ as an $\mathrm{O}_{3} / \mathrm{CO}$ anthropogenic enhancement ratio is that in the absence of photochemistry, $\mathrm{O}_{3}$ would be nega- 

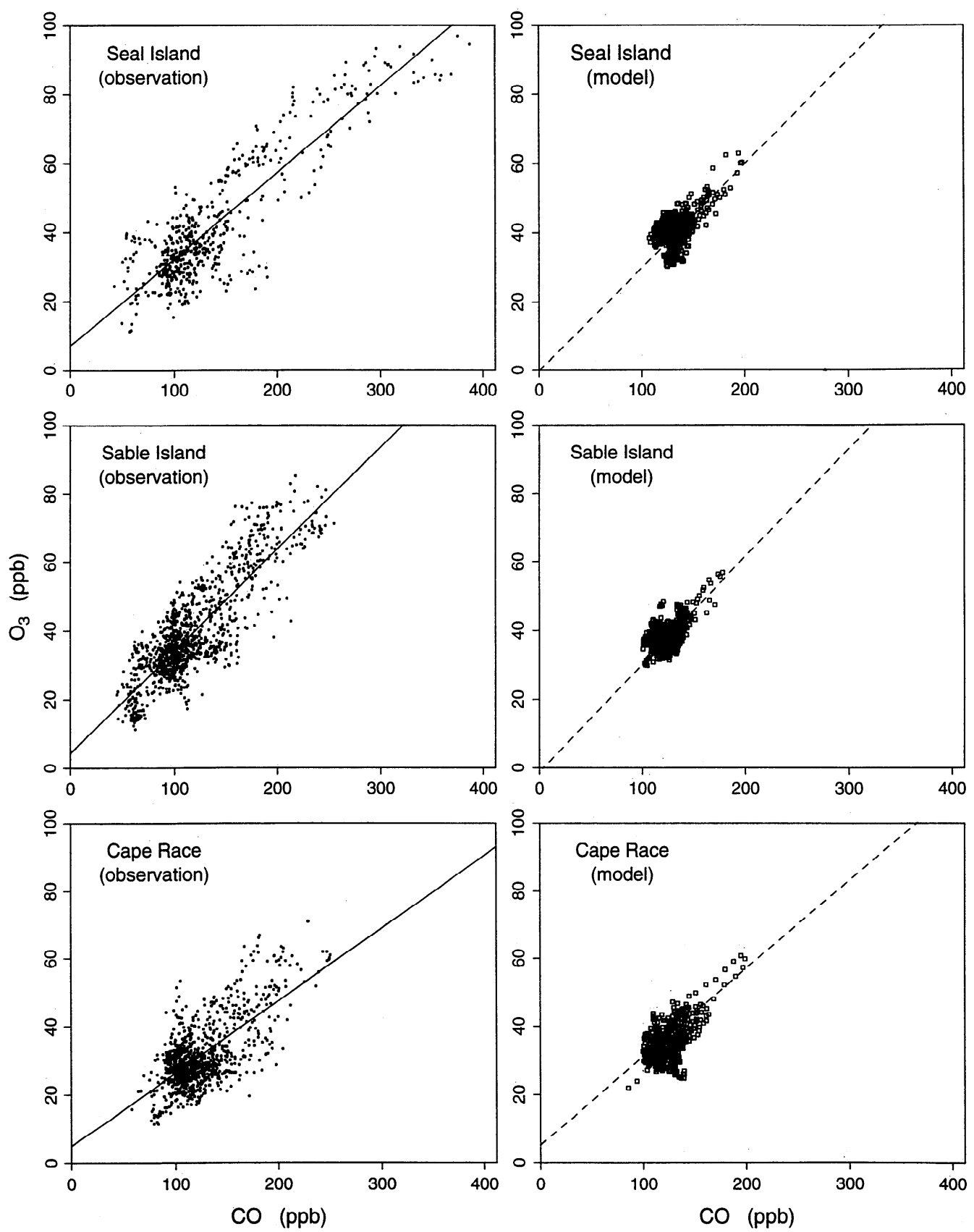

Figure 5. Observed and simulated $\mathrm{O}_{3}$ and $\mathrm{CO}$ concentrations at three Canadian marine sites (Table 1). Lines are linear regressions.

tively correlated with $\mathrm{CO}$ due to deposition. As a result, the measured $\Delta \mathrm{O}_{3} / \Delta \mathrm{CO}$ is less than the actual anthropogenic enhancement ratio. We determined the magnitude of this effect by conducting a model simulation with $\mathrm{O}_{3}$ concentrations regulated solely by advection of boundary conditions and deposition (no chemical production or loss). Figure 6 shows the results for Seal Island, Canada; without photochemistry, $\mathrm{O}_{3}$ and $\mathrm{CO}$ concentrations are negatively correlated (crosses, top panel). We can define an $\mathrm{O}_{3}$ photochemical enhancement as the difference between the $\mathrm{O}_{3}$ concentrations in the standard simulation and those in the simulation including no chemistry. This photochemical enhancement of $\mathrm{O}_{3}$ shows a strong positive correlation with $\mathrm{CO}$ (solid squares, bottom panel). The slope in the bottom panel (0.40) gives the actual $\mathrm{O}_{3} / \mathrm{CO}$ enhancement ratio from U.S. pollution; it is $33 \%$ higher than $\Delta \mathrm{O}_{3} / \Delta \mathrm{CO}$ in the top panel (0.30).

We now turn to the application of $\Delta \mathrm{O}_{3} / \Delta \mathrm{CO}$ as a measure of the $\mathrm{O}_{3}$ production efficiency. Liu et al. [1987] pointed out that the $\mathrm{O}_{3}$ production is best referenced to the loss of $\mathrm{NO}_{x}$ or, on a regional scale, the emission of $\mathrm{NO}_{x}$, since $\mathrm{O}_{3}$ production is $\mathrm{NO}_{x}$ limited. A net $\mathrm{O}_{3}$ production efficiency $\varepsilon_{N}$ was defined by Lin et al. [1988] as the net number of $\mathrm{O}_{3}$ molecules produced per $\mathrm{NO}_{x}$ molecule consumed. By scaling the observed $\Delta \mathrm{O}_{3} / \Delta \mathrm{CO}$ in photochemically aged air to a $\mathrm{CO} / \mathrm{NO}_{x}$ source ratio, we can obtain an estimate of the net $\mathrm{O}_{3}$ production efficiency $\varepsilon_{N}$; such an estimate is however a lower limit because of deposition of $\mathrm{O}_{3}$. The $\mathrm{CO} / \mathrm{NO}_{x}$ source 
ratio for the eastern United States, as defined in Figure 1, is 5.6 (using the net $\mathrm{CO}$ source in Table 2 and the NAPAP emission inventory for $\mathrm{NO}_{x}$ ). From $\Delta \mathrm{O}_{3} / \Delta \mathrm{CO}=0.3$, we obtain a net $\mathrm{O}_{3}$ production efficiency $\varepsilon_{N}$ of 1.7 in eastern U.S. boundary layer. In comparison a value of 8.5 for $\varepsilon_{N}$ at Scotia and at Egbert, Ontario, was estimated by Trainer et al. [1993] using observations of $\Delta \mathrm{O}_{3} / \Delta\left(\mathrm{NO}_{y}-\mathrm{NO}_{x}\right)$, and Olszyna et al. [1993] found a $\varepsilon_{N}$ value of 12 at Tennessee using the same relationship; these values would be upper limits for $\varepsilon_{N}$ because of rapid $\mathrm{HNO}_{3}$ deposition. Our threedimensional model gives a mean value $\varepsilon_{N}=4.2$ for the eastern United States [Jacob et al., 1993b], which is intermediate between the lower and the upper limits imposed by the observations of $\Delta \mathrm{O}_{3} / \Delta \mathrm{CO}$ and $\Delta \mathrm{O}_{3} / \Delta\left(\mathrm{NO}_{y}-\mathrm{NO}_{x}\right)$.

We have seen that deposition of $\mathrm{O}_{3}$ is an important factor limiting the potential for simple interpretation of the $\mathrm{O}_{3}-\mathrm{CO}$ correlation in terms of $\mathrm{O}_{3}$ production. Model results indicate that this effect is greatest in the central United States, where $\mathrm{O}_{3}$ concentrations would be at a minimum in the absence of photochemistry because of the long fetch in the continental boundary layer [Jacob et al., 1993a]. Figure 7 shows $\mathrm{O}_{3}-\mathrm{CO}$ correlations for the Oregon, Nebraska, Illinois, and Massachusetts grid boxes; there is no significant correlation between $\mathrm{O}_{3}$ and $\mathrm{CO}$ in the Nebraska grid box. By subtracting the $\mathrm{O}_{3}$ concentration computed in the absence of photochemistry (as in Figure 6), we obtain a strong correlation between $\mathrm{O}_{3}$ photochemical enhancement and $\mathrm{CO}$ (solid squares in Figure 7). The slope of the linear regression analysis of the $\mathrm{O}_{3}$ photochemical enhancement versus $\mathrm{CO}$ falls within a narrow range $(0.33$ to 0.49$)$ for the four grid boxes in Figure 7 and is actually highest in the Nebraska grid box.

\section{Conclusion}

Observations at nonurban sites in eastern North America show a strong correlation between $\mathrm{O}_{3}$ and $\mathrm{CO}$ concentrations in photochemically aged air (as defined by $\mathrm{NO}_{x} / \mathrm{NO}_{y}<$ $0.3)$. The slope, $\Delta \mathrm{O}_{3} / \Delta \mathrm{CO}$, has a remarkably uniform value of about 0.3. Observations at Niwot Ridge, Colorado, indicate $\Delta \mathrm{O}_{3} / \Delta \mathrm{CO}=0.15$ in the aged Denver plume; this low value is attributed to the low $\mathrm{NO}_{x} / \mathrm{CO}$ emission ratio in the Denver metropolitan area.

The $\mathrm{O}_{3}-\mathrm{CO}$ relationship provides a sensitive test of $\mathrm{O}_{3}$ production in chemical transport models. We used it to test

Table 2. Budget of CO for the Boundary Layer of the Eastern United States

\begin{tabular}{lr}
\hline \multicolumn{1}{c}{ Sources } & $\begin{array}{r}\text { Rate, } \\
\mathrm{Gmol} \mathrm{d}^{-1}\end{array}$ \\
\hline $\begin{array}{l}\text { Anthropogenic emission } \\
\text { Oxidation of isoprene }\end{array}$ & 3.3 \\
$\begin{array}{l}\text { Oxidation of anthropogenic NMHCs } \\
\text { Oxidation of } \mathrm{CH}_{4}\end{array}$ & 1.1 \\
Reaction with $\mathrm{OH}$ & 0.5 \\
Net $\mathrm{CO}$ source & 0.6 \\
\hline
\end{tabular}

This budget is based on model results from June to August for the region enclosed by thick lines in Figure 1. Anthropogenic emission is from the National Acid Precipitation Assessment Program inventory. NMHCs, nonmethane hydrocarbons.
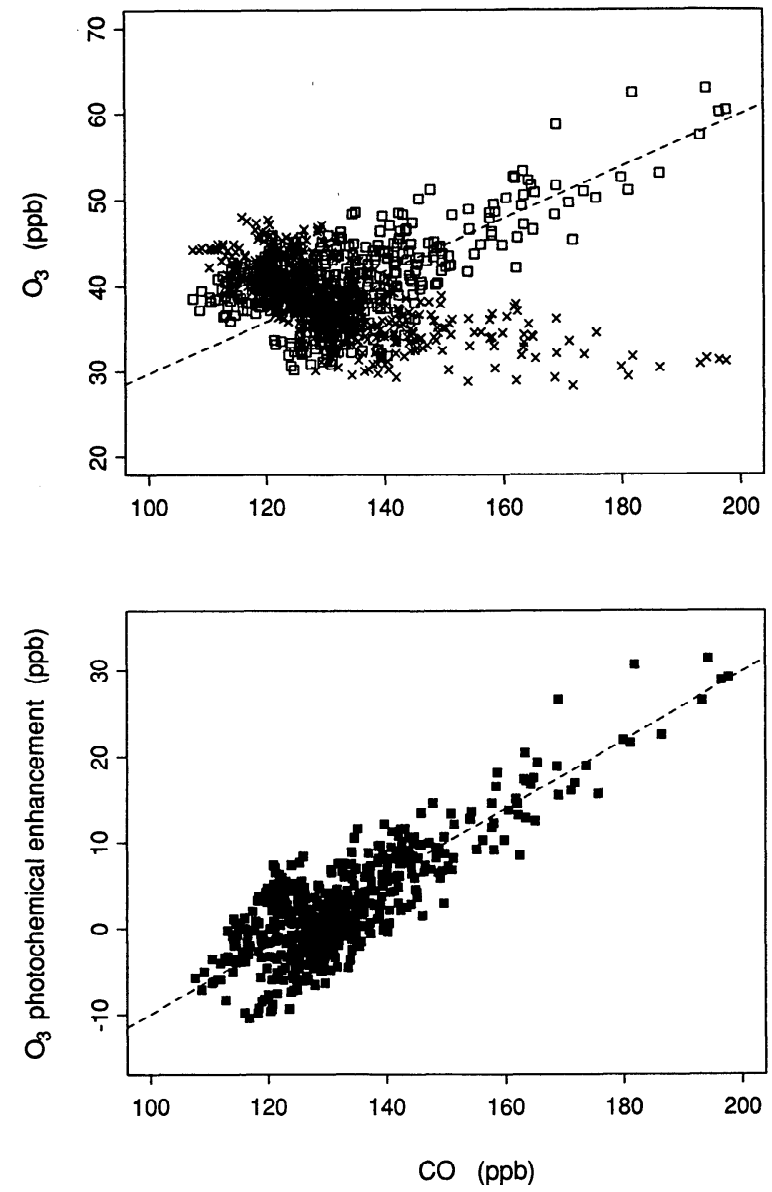

Figure 6. Simulated $\mathrm{O}_{3}$ and $\mathrm{CO}$ concentrations at Seal Island, Canada, in the model. The top panel shows $\mathrm{O}_{3}$ in the standard simulation (open squares) and in a simulation with no photochemistry (crosses); the bottom panel shows the $\mathrm{O}_{3}$ photochemical enhancement defined as the difference. The lines are linear regressions to standard $\mathrm{O}_{3}$ and $\mathrm{CO}$ (top panel) and to $\mathrm{O}_{3}$ photochemical enhancement and $\mathrm{CO}$ (bottom panel).

a three-dimensional, continental-scale model of $\mathrm{O}_{3}$ and precursors over North America [Jacob et al., 1993a]. The model captures successfully the $\mathrm{O}_{3}$ - $\mathrm{CO}$ correlations and reproduces closely the observed $\Delta \mathrm{O}_{3} / \Delta \mathrm{CO}$. It does not capture the full extent of variance in the observations, certainly in part because of spatial averaging on the grid scale. Simulation of the $\mathrm{O}_{3}$-CO relationship lends confidence in the ability of the model to compute photochemical production of $\mathrm{O}_{3}$ over North America and its export to the global atmosphere [Jacob et al., 1993b].

We investigated the possibility for a more direct interpretation of observed $\Delta \mathrm{O}_{3} / \Delta \mathrm{CO}$ as an $\mathrm{O}_{3} / \mathrm{CO}$ anthropogenic enhancement ratio, to be multiplied by a $\mathrm{CO}$ source estimate for quantitative inference of photochemical $\mathrm{O}_{3}$ production and export. A first complication with this simple approach is the need to account for chemical sources and sinks of $\mathrm{CO}$, even in a highly polluted region such as the eastern United States. A second complication is that $\mathrm{O}_{3}$ concentrations over polluted regions include a major component advected from outside the region, which is negatively correlated with $\mathrm{CO}$ due to deposition at the surface. As a result, $\Delta \mathrm{O}_{3} / \Delta \mathrm{CO}$ measured at sites over the United States and downwind is 

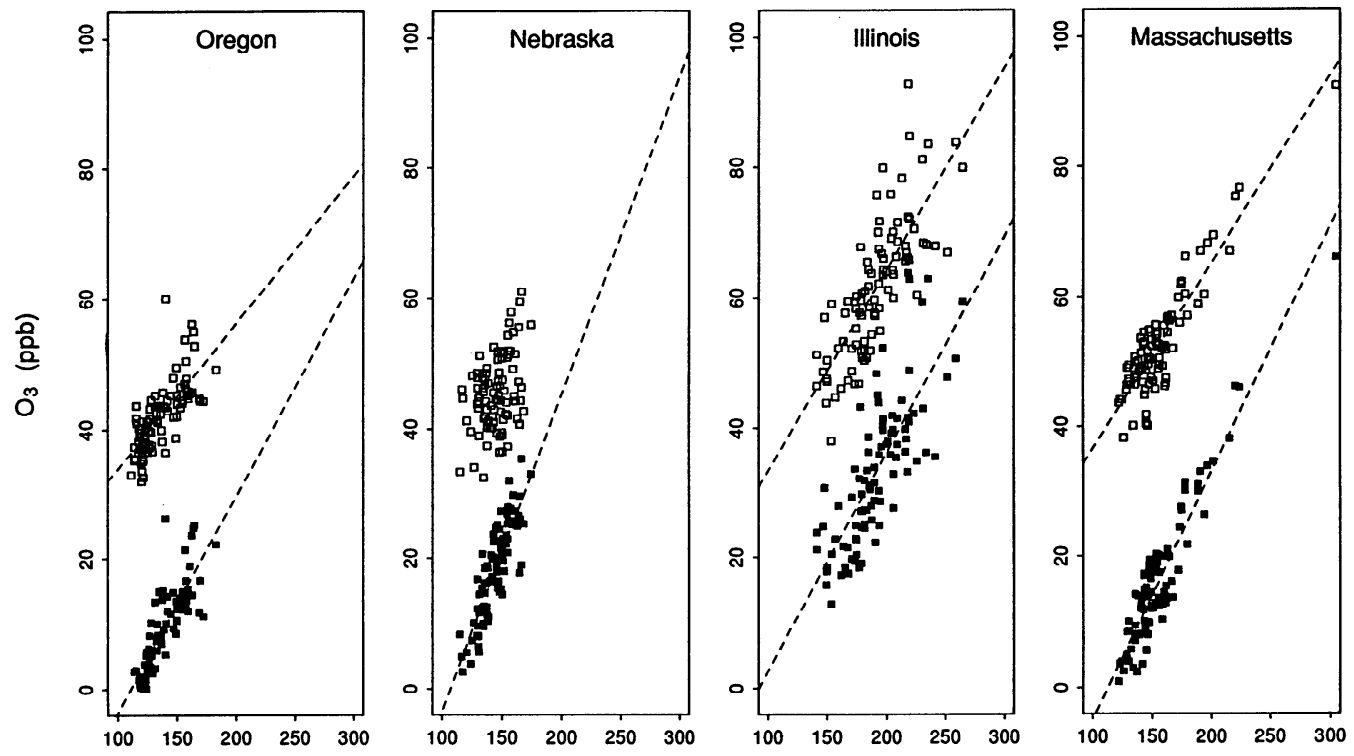

$\mathrm{CO}(\mathrm{ppb})$

Figure 7. Simulated $\mathrm{O}_{3}$ and CO concentrations in June to August (1200-1500 LT) for the Oregon, Nebraska, Illinois, and Massachusetts surface grid boxes. The open squares show $\mathrm{O}_{3}$ concentrations from the standard simulation; the solid squares show the $\mathrm{O}_{3}$ photochemical enhancement. The slopes and correlations for standard $\mathrm{O}_{3}$ versus $\mathrm{CO}$ are Oregon, slope $=0.22, r^{2}=0.53$; Nebraska, no significant correlation $\left(r^{2}=0.15\right)$; Illinois, slope $=0.31, r^{2}=0.61$; and Massachusetts, slope $=0.29, r^{2}=0.81$. The slopes and correlations for the $\mathrm{O}_{3}$ photochemical enhancement versus $\mathrm{CO}$ are Oregon, slope $=0.39$, $r^{2}=0.74$; Nebraska, slope $=0.49, r^{2}=0.74$; Illinois, slope $=0.33, r^{2}=0.60$; and Massachusetts, slope $=0.39, r^{2}=0.87$.

significantly less than the $\mathrm{O}_{3} / \mathrm{CO}$ anthropogenic enhancement ratio, and the direct interpretation of observed $\Delta \mathrm{O}_{3} /$ $\Delta \mathrm{CO}$ may underestimate substantially the $\mathrm{O}_{3}$ production and export.

From the $\Delta \mathrm{O}_{3} / \Delta \mathrm{CO}$ observed in the eastern United States scaled to a CO/NO ${ }_{x}$ source ratio for the region, we infer a lower limit of 1.7 for the net $\mathrm{O}_{3}$ production efficiency $\varepsilon_{N}$ defined as the net number of $\mathrm{O}_{3}$ molecules produced per molecule of $\mathrm{NO}_{x}$ consumed. This value is a lower limit because of $\mathrm{O}_{3}$ deposition. Observations of $\Delta \mathrm{O}_{3} / \Delta\left(\mathrm{NO}_{y^{-}}\right.$ $\mathrm{NO}_{x}$ ) in the eastern United States yield values of 8.5-12 for $\varepsilon_{N}$; these values are upper limit because of rapid $\mathrm{HNO}_{3}$ deposition. The mean $\varepsilon_{N}$ value of 4.2 computed in the three-dimensional model for the boundary layer of the eastern United States falls within the limits imposed by the observations of $\Delta \mathrm{O}_{3} / \Delta \mathrm{CO}$ and $\Delta \mathrm{O}_{3} / \Delta\left(\mathrm{NO}_{y}-\mathrm{NO}_{x}\right)$.

Acknowledgments. We thank Steve Wofsy and Jennifer Logan for their comments and suggestions. This work was supported by grants to Harvard University (National Science Foundation, NSF93-04217 and NSF-BSR-8919300; the National Aeronautics and Space Administration, NASA-NAGW-3082; Environmental Protection Agency, EPA-R814535-01-0; Department of Energy, Northeastern Center of the Global Environmental Change; and the Packard Foundation), grants to the University of Maryland (Environmental Protection Agency, EPA-R814526 and National Science Foundation, ATM-86-19491 and ATM-90-14841), and part of the Climate and Global Change Program by the National Oceanic and Atmospheric Administration.

\section{References}

Chameides, W. L., D. D. Davis, M. O. Rodgers, J. Bradshaw, S. Sandholm, G. Sachse, G. Hill, G. Gregory, and R. Rasmussen,
Net ozone photochemical production over the eastern and central north Pacific as inferred from CTE/CITE 1 observations during fall 1983, J. Geophys. Res., 92, 2131-2152, 1987.

Chameides, W. L., D. D. Davis, G. L. Gregory, G. Sachse, and A. L. Torres, Ozone precursors and ozone photochemistry over eastern North Pacific during the spring of 1984 based on the NASA GTE/CITE 1 airborne observations, J. Geophys. Res., 94, 9799-9808, 1989.

Chameides, W. L., et al., Ozone precursor relationships in the ambient atmosphere, J. Geophys. Res., 97, 6037-6055, 1992.

Doddridge, B. G., R. R. Dickerson, R. G. Wardell, K. L. Civerolo, and L. J. Nunnermacker, Trace gas concentrations and meteorology in rural Virginia, 2, Reactive nitrogen compounds, J. Geophys. Res., 97, 20,631-20,646, 1992.

Environmental Protection Agency (EPA), The 1985 NAPAP emission inventory (version 2): Development of the annual data and modeler's tapes, Rep. EPA-600/7-89-012a, Environ. Prot. Agency, Research Triangle Park, N. C., 1989.

Fishman, J., and W. Seiler, Correlative nature of ozone and carbon monoxide in the troposphere: Implications for the tropospheric ozone budget, J. Geophys. Res., 88, 3662-3670, 1983.

Fishman, J., G. L. Gregory, G. W. Sachse, S. M. Beck, and G. F. Hill, Vertical profiles of ozone, carbon monoxide, and dew point temperature obtained during GTE/CITE 1, October to November 1983, J. Geophys. Res., 92, 2083-2094, 1987.

Hansen, J., G. Russell, D. Rind, P. Stone, A. Lacis, S. Lebedeff, R. Ruedy, and L. Travis, Efficient three-dimensional global models for climate studies: Models I and II, Mon. Weather Rev., 111, 609-662, 1983.

Harriss, R. C., et al., The Arctic Boundary Layer Expedition (ABLE 3A): July to August 1988, J. Geophys. Res., 97, 16,38316,394, 1992.

Harriss, R. C., et al., The Arctic Boundary Layer Expedition (ABLE 3B): July to August 1990, J. Geophys. Res., 99, 1635$1643,1994$.

International Global Atmospheric Chemistry (IGAC), Core Project Office, International Global Atmospheric Chemistry (IGAC) Project: An Overview, MIT Press, Cambridge, Mass., 1992. 
Jacob, D. J., S. Sillman, J. A. Logan, and S. C. Wofsy, Least independent variables method for simulation of tropospheric ozone, J. Geophys. Res., 94, 8497-8509, 1989.

Jacob, D. J., et al., Simulation of summertime ozone over North America, J. Geophys. Res., 98, 14,797-14,816, 1993a.

Jacob, D. J., J. A. Logan, G. M. Gardner, R. M. Yevich, C. M. Spivakovsky, S. C. Wofsy, S. Sillman, and M. J. Prather, Factors regulating ozone over the United States and its export to the global atmosphere, J. Geophys. Res., 98, 14,817-14,826, 1993b.

Leighton, P. A., Photochemistry of Air Pollution, Academic, San Diego, Calif., 1961.

Lin, X., M. Trainer, and S. C. Liu, On the nonlinearity of the tropospheric ozone production, J. Geophys. Res., 93, 15,87915,888, 1988.

Liu, S. C., M. Trainer, F. C. Fehsenfeld, D. D. Parrish, E. J. Williams, E. W. Fahey, G. Hubler, and P. C. Murphy, Ozone production in the rural troposphere and the implications for regional and global ozone distribution, J. Geophys. Res., 92, 4191-4207, 1987.

Logan, J. A., M. J. Prather, S. C. Wofsy, and M. B. McElroy, Tropospheric chemistry: A global perspective, J. Geophys. Res., $86,7210-7254,1981$.

Lurmann, F. W., A. C. Lloyd, and R. Atkinson, A chemical mechanism for use in long-range transport/acid deposition computer modeling, J. Geophys. Res., 91, 10,905-10,936, 1986.

Madronich, S., Intercomparison of $\mathrm{NO}_{2}$ photodissociation and u.v. radiometer measurements, Atmos. Environ., 21, 569-578, 1987.

Marenco, A., and F. Said, Meridional and vertical ozone distribution in the background troposphere $\left(70^{\circ} \mathrm{N}-60^{\circ} \mathrm{S} ; 0-12 \mathrm{~km}\right.$ altitude) from scientific aircraft measurements during the STRATOZ III experiment (June 1984), Atmos. Environ., 23, 201-214, 1989.

Mauzerall, D. L., D. J. Jacob, S.-M. Fan, J. D. Bradshaw, S. T. Sandholm, D. R. Blake, G. L. Gregory, and G. W. Sachse, An ozone budget for the remote troposphere over eastern Canada, Eos Trans. AGU, 74, Fall Meeting suppl., 74(43), 180, 1993.

McKeen, S. A., E.-Y. Hsie, M. Trainer, R. Tallamraju, and S. C. Liu, A regional model study of the ozone budget in the eastern United States, J. Geophys. Res., 96, 10,809-10,845, 1991.

Olszyna, K. J., E. M. Bailey, and J. F. Meagher, $\mathrm{O}_{3}$ and $\mathrm{NO}_{\mathrm{y}}$ relationships at a rural site in Tennessee, Eos Trans. AGU, 74, Spring Meeting suppl., 74(16), 66, 1993.

Parrish, D. D., et al., Systematic variations in the concentration of $\mathrm{NO}_{x}$ (NO plus $\mathrm{NO}_{2}$ ) at Niwot Ridge, Colorado, J. Geophys. Res., $95,1817-1836,1990$
Parrish, D. D., M. Trainer, M. P. Buhr, B. A. Watkins, and F. C. Fehsenfeld, Carbon monoxide concentrations and their relation to concentrations of total reactive oxidized nitrogen at two rural U.S. sites, J. Geophys. Res., 96, 9309-9320, 1991.

Parrish, D. D., J. S. Holloway, M. Trainer, P. C. Murphy, G. L. Forbes, and F. C. Fehsenfeld, Export of North American ozone pollution to the North Atlantic Ocean, Science, 259, 1436-1439, 1993.

Poulida, O., R. R. Dickerson, B. G. Doddridge, J. Z. Holland, R. G. Wardell, and J. G. Watkins, Trace gas concentrations and meteorology in rural Virginia, 1, Ozone and carbon monoxide, $J$. Geophys. Res., 96, 22,461-22,475, 1991.

Sillman, S., J. A. Logan, and S. C. Wofsy, A regional scale model for ozone in the United States with subgrid representation of urban and power plant plumes, J. Geophys. Res., 95, 5731-5748, 1990a.

Sillman, S., J. A. Logan, and S. C. Wofsy, The sensitivity of ozone to nitrogen oxides and hydrocarbons in regional ozone episodes, J. Geophys. Res., 95, 1837-1851, 1990b.

Thompson, A. M., The oxidizing capacity of the Earth's atmosphere: Probable past and future changes, Science, 256, 11571168, 1992.

Trainer, M., E. Y. Hsie, S. A. McKeen, R. Tallamraju, D. D. Parrish, F. C. Fehsenfeld, and S. C. Liu, Impact of natural hydrocarbons on hydroxyl and peroxy radicals at a remote site, $J$. Geophys. Res., 92, 11,879-11,894, 1987.

Trainer, M., et al., Correlation of ozone with $\mathrm{NO}_{y}$ in photochemically aged air, J. Geophys. Res., 98, 2917-2925, 1993.

Wendland, W. M., and R. A. Bryson, Northern hemisphere airstream regions, Mon. Weath. Rev., 109, 255-270, 1981.

Wofsy, S. C., et al., Atmospheric chemistry in the Arctic and subarctic: Influence of natural fires, industrial emissions, and stratospheric inputs, J. Geophys. Res., 97, 16,731-16,746, 1992.

M. Chin, D. J. Jacob, and W. Munger, Division of Applied Sciences and Department of Earth and Planetary Sciences, Harvard University, Cambridge, MA 02138.

B. G. Doddridge, Department of Meteorology, University of Maryland, College Park, MD 20742.

D. D. Parrish, NOAA Aeronomy Laboratory, Boulder, CO 80303.

(Received November 23, 1993; revised March 25, 1994; accepted April 1, 1994.) 